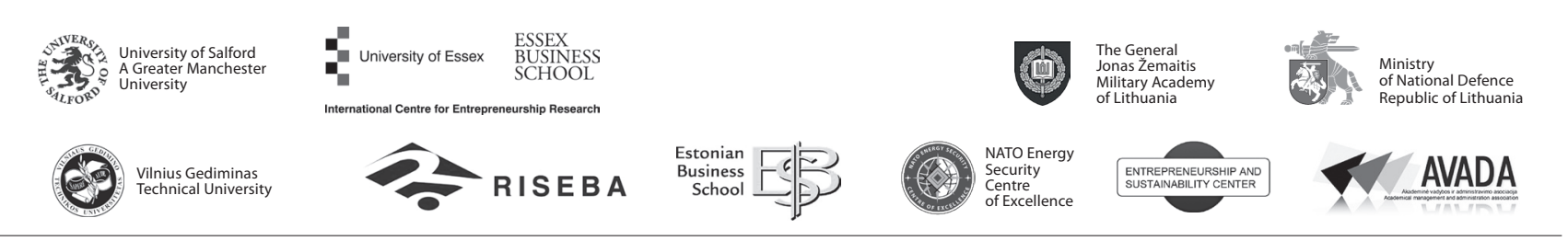

\author{
JOURNAL OF SECURITY AND SUSTAINABILITY ISSUES \\ ISSN 2029-7017 print/ISSN 2029-7025 online \\ 2017 September Volume 7 Number 1 \\ http://dx.doi.org/10.9770/jssi.2017.6.1(7)
}

\title{
CREDIT RISK MANAGEMENT: FINANCIAL SAFETY AND SUSTAINABILITY ASPECTS
}

\author{
Jaroslav Belás ${ }^{1}$, Mária Mišanková2 ${ }^{2}$ Jaroslav Schönfeld ${ }^{3}$, Beáta Gavurová ${ }^{4}$ \\ ${ }^{1}$ Tomas Bata University in Zlín, Faculty of Management and Economics, Mostni 5139, 76000 Zlín, Czech Republic \\ ${ }^{2}$ University of Zilina, Faculty of Operation and Economics of Transport and Communications, \\ Univerzitna 1, 01026 Zilina, Slovakia \\ ${ }^{3}$ University of Economics Prague, Faculty of Business Administration, nám. W. Churchulla 4, \\ Prague, 130 67, Czech Republic \\ ${ }^{4}$ Technical University of Košice, Faculty of Economics, Němcovej 32, 04001 Košice, Slovakia \\ E-mails: ${ }^{1}$ belas111@gmail.com; ${ }^{2 m a r i a . m i s a n k o v a @ f p e d a s . u n i z a . s k ; ~}$ \\ 3jaroslav.schonfeld@vse.cz; ${ }^{4}$ beata.gavurova@tuke.sk
}

Received 25 January 2017; accepted 19 May 2017

\begin{abstract}
Financial security of companies is of the strategic importance. An effective credit risk management greatly impacts on a company security because its failure can threaten the existence of the company. These aspects are closely related to the sustainability of the SME sector, which is determined by many negative processes in the current post-crisis period. The aim of this article is to research the dependence between the entrepreneur's ability to manage the credit risk in their company effectively and their knowledge of the corporate capital. Within the set goal, we looked at the differences in the attitudes of entrepreneurs depending on a company size, gender and education of entrepreneurs. To analyze acquired data, we used descriptive statistics, regression analyses and Z-score in our research. The originality of the article is that the whole process and result trajectory is focused on highlighting the financial security and sustainability of the searched sector. The results of our research brought an interesting finding. On the one hand, entrepreneurs declared a high capability of the effective credit risk management in their companies and, on the other hand, demonstrated a low level of knowledge in managing the corporate capital. This trend creates a potential possibility of a growth of corporate financial risks. The research results confirmed that the theoretical knowledge of the corporate capital has a significant impact on the formation of effective attitudes of the entrepreneur to manage the credit risk. Larger companies, men and entrepreneurs with higher education have much better level of knowledge of the corporate capital management. The research results enable to form a platform for a deeper insight into the financial security processes in companies and in the sustainability of the SME sector, especially in the current post-crisis period.
\end{abstract}

Keywords: corporate financial safety, small and medium sized companies, credit risk, management of credit risk

Reference to this paper should be made as follows: Belás, J.; Mišanková, M.; Schönfeld, J.; Gavurová, B. 2017. Credit risk management: financial safety and sustainability aspects, Journal of Security and Sustainability Issues 7(1): 79-93.

http://dx.doi.org/10.9770/jssi.2017.6.1(7)

JEL Classifications: D81, G21, G31

\section{Introduction}

Small and medium sized enterprises represent the primary moving mechanism for creation of a new job and increase of the gross domestic product (Czarniewski, 2016; Tvaronavičienè, 2016), their growth and development are the priorities amongst the goals of national economies for developed countries of the world as well as for countries in transition (Kozarevic et. al., 2015, Virglerová et al., 2016, Krejčí et. al., 2015; Munteanu, Tamošiūnienè, 2015; Travkina, Tvaronavičienè, 2015). The issue of business risks of small and medium enterprises (SMEs) represents a current area of theoretical research and practical applications (Ključnikov, Popesko, 


\section{7; Havernikova et al., 2016; Merigó, 2015).}

A financial security of companies is a strategic management area, as every company has the prospect of staying in the market and increasing its value (Pavelková and Knápková, 2005, Kislingerová et al., 2010; Stasytytė and Aleksienè, 2015).

An efficient corporate credit risk management is a significant area of an overall management because many businesses are directly dependent on external financing in the form of bank loans. In the case of efficient corporate credit risk management, they use the financial leverage to accelerate their business activities. On the other hand, the excessive debt ratio necessarily implies a limitation of the debtor's rights, which may lead to the discovery of the bankruptcy. In such a case, the debtor is wholly forbidden from controlling its assets. This is also in the case when the default is solved by a bankruptcy. In the case of a rescue, the debtor's dispositional rights are subject to the supervision of the creditors (Smrčka et al., 2016).

Thus, unsuccessful credit risk management can lead to the termination of a company. In this context, Pavelka and Krchnak (2015) pay attention to the fact that SMEs have more difficult access to foreign financial resources for their development and increased competitiveness.

The global economic crisis meant a serious external shock for the SME segment, and in many cases also jeopardized the existence of these businesses. Enterprises in the SME segment experienced a significant drop in demand, orders, and worsening of sales over the period, which subsequently resulted in lower sales, worse profitability and decrease of liquidity. Low return on investment provoked problems with repayment of loans and liabilities to suppliers and employees, which led to the creation of the secondary insolvency and threatened the operation of other businesses. Banks and credit institutions tightened credit standards, increasing the difficulty of credit obtaining and the costs of repayment. For SMEs, the access to external funding worsen significantly and so their liquidity. These processes associated with the crisis and the post-crisis periods put increased demands on the financial management in companies and on the application of various financial scenarios. This aspect is strongly related to the level of knowledge of the credit risk and corporate capital management. Requirements for this knowledge have changed significantly in recent years. It is not enough to have only basic knowledge and experience in the field of the financial management, entrepreneurs are getting in their management regime into much more complex decision-making problems that determine their existence.

In a reflection of the facts presented, we see the current issues of SME in two lines - at the micro level - represented by the financial security of SMEs (Akhmadeev, Manakhov, 2015), and at the macro level - represented by the sustainability of the SME sector (Astrauskaite, Paškevičius, 2016; Giriūnienè, G.; Giriūnas, L. 2015).

There is a causal conditional relationship between the financial security of SMEs and their sustainability in this sector that has not been the subject of any research studies yet. This is due to the problematic capture of their qualitative and quantitative links, which are complicated by dynamic changes in the external environment of the SMEs. This also raises the need for methodological processes, as well as the available data base. This consistent fact instilled us, in the initial stages, the need for a deeper research of selected aspects of the effective risk management of SME entrepreneurship in relation to the financial security of companies and the creation of a macroeconomic trajectory of the impacts of these aspects on the global sustainability of the SME sector.

The originality of this article lies in the research of the dependence of the credit risk management on the knowledge of the basic rules of the corporate capital management. Our article is based on the empirical knowledge which we gained in the segment of small and medium sized enterprises using the questionnaire research.

The structure of this article is as follows. The introductory theoretical part represents a brief excursion to the problem solved and is aimed at clarifying of the importance of the processes of monitoring and evaluating of the financial security of enterprises in the current post-crisis period and its interconnectivity to the macro 
level - the sustainability of the SME sector. In the next part, we focus on the research processes, where we describe in detail the methodology of the research and the main research lines. The results of the analyses are the subject of the third part, in which the research findings of both quantitative and qualitative characters are aggregated. In the context of the highlighting of the significance of the financial security processes of SMEs and the sustainability of the sector, in the discussion part we point out also to the risks of the company insolvency, its global situation and the attitudes of Czech and Slovak entrepreneurs towards this fact. The discussion line ends with the institutional usability of the results of our research and inspirational ideas for the further research.

\section{Theoretical background}

According to Leopoulos et. al. (2006) managing of financial and credit risk should be a fundamental part of everyday activities of SMEs. Authors presented explicit quantitative tools for its successful management (Kulišauskas, Galinienè, 2015; Tamulevičienè, 2016).

Similarly, Stan-Maduka (2013) stressed the necessary role of financial risk management and assessment in the business processes and profitability of SMEs. In this context Kozubíková et al. (2017) state that financial risk is considered to be one of the most important types of risk because high financial risk-taking may in turn significantly affect the liquidity of the company.

The strong relations between credit risk, macroeconomic conditions and capital structure was analysed by Hackbarth et. al. (2006) introducing the model for measuring the impact of various capital structure on credit risk.

The leverage effect in terms of capital structure and its influence on corporate credit risk management is highlighted also by Purnanandam (2008). Grossl et. al. (2001) provided an investigation of German companies' financial structure in context of financial risk of SMEs, while finding out that positive trend of owing leads to significant higher financial risk of the company. In the same way Kim et. al. (2011) studied the leverage impact on corporate cash holdings in Korean SMEs in context of financial risk.

Furthermore, Dangl and Zechner (2004) proved that dynamic capital structure lower optimal initial leverage ratios while increasing credit spreads and expected default probabilities. The research of these authors has shown that the extent of the effect of capital structure dynamics depends mainly on firm characteristics, such as asset volatility, the growth rate, the effective corporate tax rate, debt call features and transactions costs. Equally Behr and Guttler (2007) state that the value of loans of SMEs have direct impact on their credit risk.

On the other side some authors state that effective credit risk management involves not only management of financial indicators and considering economic conditions, but also it is important to evaluate SME characteristics, such as firm-specific characteristics (Moon and Sohn, 2010; Felicio et al., 2015).

According to Gupta et. al. (2015) successful credit risk management depends strongly on the size of the company. They argue that within the broad category of small and medium size enterprises exists a huge diversity, as SME differ widely in their capital structure, firm size, access to external finance, management style, numbers of employees etc., which is important to consider while managing credit risk.

Similarly, Marshall et. al. (1996) have dealt with the importance of knowledge management in context of financial risk. Their results further suggest that there is a need for a more structured approach to transferring knowledge to decision makers before it is needed, enabling the access of information as it is needed and transferring the knowledge about the firm's changing risk management requirements.

The value of non-financial information in SME companies credit risk management is highlighted also by Altman et. al. (2010) and Kritzman and Li (2010). In the same way Chen (2016) studied the influence of geography characteristics of companies on the credit risk. The study provided in Taiwan showed that the firm loca- 
tion affects credit risk through the channels of incomplete information and financial leverage. Moreover, the study found out that a firm's market-debt financing distance is positively associated with its credit risk while the firm's banking-debt financing distance has insignificant effect.

Kozubikova and Bartos (2015) provided the examination of the relationship between personality characteristics and approach to the perception and management of credit risks. They proved that there are significant differences in approaching credit risk between artist-entrepreneurs and businessmen-laborers. The results further showed a high degree of confidence of individual groups of entrepreneurs when evaluating their ability to manage financial risks in the company. Same groups of entrepreneurs were studied also by Kozubikova et. al. (2015). They proved the high degree of confidence of individual groups of entrepreneurs when evaluating their ability to manage financial risks in the company and the high intensity of entrepreneurial optimism regardless of the personal characteristics of entrepreneurs. The results by Kozubíková et al. (2017) show that there are differences between men and women entrepreneurs in factors which are important for the perception of financial risk.

The authors pay much attention to other attributes of the corporate credit risk management. Size of the company can play an important role in the context of external funds obtaining (Pervan, Kuvek, 2013). Credit tightening that followed the crisis has affected some SMEs more than others (Bain \& Company, Inc. and the IIF (2013). The access to finance is one major challenge for SMEs, which affects them disproportionately more than large firms (International Finance Corporation, 2013), especially in the conditions of the financial distress, when SMEs are often denied for credit (Kundin \& Erecgovac, 2011). The reason can be the asymmetry of information in the credit process (Ramlee \& Berma, 2013).

Many authors research the relation of the gender to the financial risk. Diaz-Garcia and Jimenez-Moreno (2010), Ayub et al. (2013) and Lim and Envick (2011) identically found that women are more risk averse than men. On the other hand, Garwe and Fatoki (2012) confirmed that gender does not have any significant impact on SME finance, however, females were more discouraged from bank finance than males. Gamage (2013) also negated the influence of the gender and the experience of the entrepreneur.

The importance of education for the entrepreneurship of SMEs is searched by other authors. According to Irwin and Scott (2010), higher education of the entrepreneurs has a positive impact on the ability to undergo financial difficulties and provide better access to the external funding. Higher educated people are more interested to have their own business (Velez, 2009; Lafuente, Vaillant, 2013). Educated individuals can look for more opportunities in the market (Naude et al., 2008), which is positively related to higher growth (Rauch, Rijsdijk, 2013, Van der Sluis and Van Praag, 2008).

\section{Aim, methodology and data}

The aim of this article is to search the dependence between the entrepreneur's ability to manage the corporate credit risk effectively and their knowledge of the corporate capital.

Within the set goal, we searched the differences in the attitudes of entrepreneurs, depending on the size of business, gender, and entrepreneurship education.

In connection with the defined goal, in 2017 we realized an empirical research in the Czech business environment of SMEs using a questionnaire. Entrepreneurs and business managers expressed their approval with the defined claims on the 5-degree Likert scale: I totally agree, I agree, I have no attitude, I disagree, I totally disagree. The questionnaire consisted of 6 questions related to the socio-demographic characteristics of enterprises (region, business sector, number of years of entrepreneurship, size of an enterprise, gender and education of an entrepreneur) and 36 claims related to the credit risk.

The procedure of obtaining empirical data was as follows. By a random numbering method, using the Randbetween mathematical function, we selected 1,000 SMEs from the official Czech database of the companies Al- 
bertína. We addressed these businesses by mail and telephone at least once, and if we had a negative response, we contacted the company again. The sample presented 352 enterprises (35\% success rate) with the received feedback. Data were collected in all regions of the Czech Republic.

The structure of socio-demographic characteristics of entrepreneurs was as follows: males 265 (75.4\%), women 87 (24.6\%), university education 171 (48.6\%), secondary education with graduation 139 (39.5\%), secondary education without graduation $42(11.9 \%)$. The structure of enterprises was as follows: enterprises up to $10 \mathrm{em}-$ ployees 233 (66.2\%), enterprises up to 50 employees 67 (19.0\%), enterprises up to 250 employees 52 (14.8\%). Business doing business more than 10 years in the market 227 (64.5\%), from 5 to 10 years 64 (18.2\%) and up to 5 years $61(17.3 \%)$.

The effective credit risk management was defined by the claim (indicator):

Ky: I can manage credit risk in my business effectively.

We defined the entrepreneur's knowledge of the corporate capital by the following statements (indicators):

K1: Debt (a bank loan) is cheaper than the entrepreneur's equity and therefore I use a bank loan.

K2: Debt (a bank loan) is less risky than the entrepreneur's equity and therefore I borrow money from the bank.

K3: Businesses need a certain amount of credit, but I think the entrepreneur should have more equity than loans.

K4: Debt should be used primarily to finance the current capital of the company.

The mentioned dependency can be formally written as:

$$
\begin{aligned}
& I_{\mathrm{Ky}}=\mathrm{f}(\mathrm{K} 1, \mathrm{~K} 2, \mathrm{~K} 3, \mathrm{~K} 4) \\
& \mathrm{I}_{\mathrm{Ky}} \geq \mathrm{I}_{\mathrm{Kn}} \\
& \mathrm{I}_{\mathrm{Kn}}=\left(\mathrm{I}_{\mathrm{K} 1}+\mathrm{I}_{\mathrm{K} 2}+\mathrm{I}_{\mathrm{K} 3}+\mathrm{I}_{\mathrm{K} 4}\right) / 4
\end{aligned}
$$

$\mathrm{I}_{\mathrm{Ky}}$ expresses the overall value of the ability to manage the credit risk in the company effectively, $\mathrm{I}_{\mathrm{K} 1}+\mathrm{I}_{\mathrm{K} 2}+$ $\mathrm{I}_{\mathrm{K} 3}+\mathrm{I}_{\mathrm{K} 4}$ express the value of partial indices. We assumed that the declared ability to manage the credit risks effectively would be greater or equal to the average value of knowledge in the field of the corporate capital.

The formulation of the individual indicators was determined in such a way that the higher value of the knowledge indicators determined the higher value of the effective credit risk management. The $\mathrm{I}_{\mathrm{Ky}}$ belongs to the interval $(0 ; 4)$. The lowest value means that the sum of the knowledge index values is zero. The highest value means that the sum of the knowledge index values is excellent. When formulating the statements, we used the findings of many authors (e.g. Pavelková and Knápková, 2005, Kislingerová et al., 2010).

In the article, we identified these scientific hypotheses using the expert estimation method:

$\mathrm{H} 1$ : The value of $\mathrm{I}_{\mathrm{Ky}}$ for the entire SME segment will be higher than the average theoretical value of $\mathrm{I}_{\mathrm{Ky}}(0.500)$. The values of partial $\mathrm{I}_{\mathrm{Ky}}$ calculated for individual groups of entrepreneurs will be higher than the average theoretical $\mathrm{I}_{\mathrm{Ky}}$ value $(0.500)$.

$\mathrm{H} 2$ : The value of $\mathrm{I}_{\mathrm{Kn}}$ for the entire SME segment will be higher than the average theoretical value of $\mathrm{I}_{\mathrm{Kn}}(0.500)$. The values of partial $\mathrm{I}_{\mathrm{Kn}}$ calculated for individual groups of entrepreneurs will be higher than the average theoretical $\mathrm{I}_{\mathrm{Kn}}$ value $(0.500)$.

H3: The multiple linear regression model explains more than $30 \%$ of the total variability between the dependent variable Ky and the independent variables (K1, K2, K3, K4).

H4: There are no statistically significant differences in the selected indicators by company size, gender and education.

The values given in Equations 1 and 3 were calculated for the defined groups of entrepreneurs.

We used descriptive statistics and Z-score to validate hypotheses H1-H3. Statistically significant differences 
between the positive responses of the designated social groups were compared using the Pearson statistics at the significance level of $5 \%$. If the calculated p-value was lower than $5 \%$, we reject the null hypothesis, and the alternative hypothesis was confirmed. The calculations were made using the free software available at http://www.socscistatistics.com/tests/ztest/Default2.aspx.

In order to quantify the relationship between the dependent variable and the independent variables, a regression analysis was used. Independent variables must meet the linearity assumption (verification by the graphical analysis using the "point graph"), the assumption of homoscedasticity (verification by Bartlett's test), the assumption of normal data distribution (graphical verification by comparing the histogram to the normal distribution curve and by testing the descriptive characteristics using the z-value). If the $\mathrm{z}$ - value of the descriptive characteristic (skewness, kurtosis) of the indicator is less than 2 (Hair, 2010) then the assumption of the normality is met. The relationship between the variables was searched using a correlation matrix. T-test was used to verify the significance of regression model parameters. The general form of the regression model with multiple linear function, which expresses the additive relationship between the dependent and independent variables, can be expressed as:

$$
\mathrm{Ky}=\beta_{0}+\beta_{1}{ }^{*} \mathrm{~K} 1+\beta_{2}{ }^{*} \mathrm{~K} 2+\beta_{3}^{*} \mathrm{~K} 3+\beta_{4}{ }^{*} \mathrm{~K} 4+\varepsilon \mathrm{t},
$$

Where the Ky - a dependent variable, $\beta_{0}-\mathrm{a}$ constant, $\beta_{1}, \ldots, \beta_{4}$ - parameters of independent variables, $\mathrm{K} 1, \mathrm{~K} 2$, $\mathrm{K} 3, \mathrm{~K} 4$ - independent variables, $\varepsilon \mathrm{t}$ - an error term.

The statistical significance of the regression model was verified by the $\mathrm{F}$ - test. The presence of a multi-collinearity was identified by the variance inflation factor (VIF test). If the regression model function has three or more independent variables, then a negative phenomenon, multi-collinearity, is to be verified (Noriss and Lecavalier, 2009). We used the determination coefficient (R2) to express the reliability of the regression model. In the tests required for the regression analysis, we used the probability of a test error of 0.05 . The calculations were made using the SPSS Statistics software.

\section{Results and discussion}

The results of the research are presented in the following tables. Table 1 lists the results that show the entrepreneurs' view on their ability to manage the credit risk in the company effectively.

Table 1. Ability of entrepreneurs to manage the credit risk in the company effectively

\begin{tabular}{|l|c|c|c|c|c|c|c|}
\hline $\begin{array}{c}\text { I can manage the credit risk } \\
\text { in my company effectively }\end{array}$ & $\begin{array}{c}\text { Total } \\
\text { SMEs }\end{array}$ & Micro & OE & M & W & UD & OD \\
\hline 1. totally agree & 32 & 20 & 12 & 25 & 7 & 16 & 16 \\
\hline 2. agree & 206 & 137 & 69 & 150 & 56 & 106 & 100 \\
\hline Sum 1+2 & 238 & 157 & 81 & 175 & 63 & 122 & 116 \\
\hline Total number & 352 & 233 & 119 & 265 & 87 & 171 & 181 \\
\hline Index & 0.676 & 0.674 & 0.681 & 0.660 & 0.724 & 0.713 & 0.641 \\
\hline
\end{tabular}

Notice: Micro-micro enterprises, OE-other enterprises, M-men, $W$-women, UD- university education, OD-other education

The research results, which represent the knowledge of entrepreneurs of the corporate capital management, are presented in Tables 2-5. 
Table 2. Knowledge 1

\begin{tabular}{|l|c|c|c|c|c|c|c|}
\hline $\begin{array}{c}\text { Debt is cheaper than the entrepreneur's } \\
\text { equity and therefore I use a bank loan. }\end{array}$ & $\begin{array}{c}\text { Total } \\
\text { SMEs }\end{array}$ & Micro & OE & M & W & UD & OD \\
\hline 1. totally agree & 17 & 11 & 6 & 14 & 3 & 12 & 5 \\
\hline 2.agree & 91 & 40 & 51 & 70 & 21 & 57 & 34 \\
\hline Sum 1+2 & 108 & 51 & 57 & 84 & 24 & 69 & 39 \\
\hline Total number & 352 & 233 & 119 & 265 & 87 & 171 & 181 \\
\hline Index & 0.307 & 0.219 & 0.479 & 0.317 & 0.276 & 0.404 & 0.215 \\
\hline
\end{tabular}

Table 3. Knowledge 2

\begin{tabular}{|c|c|c|c|c|c|c|c|}
\hline $\begin{array}{l}\text { Debt (a bank loan) is less risky than the } \\
\text { entrepreneur's equity and therefore I } \\
\text { borrow money from the bank. }\end{array}$ & $\begin{array}{c}\text { Total } \\
\text { SMEs }\end{array}$ & Micro & $\mathrm{OE}$ & M & $\mathrm{W}$ & UD & OD \\
\hline 1. totally agree & 6 & 3 & 3 & 4 & 2 & 4 & 2 \\
\hline 2.agree & 56 & 31 & 25 & 43 & 13 & 30 & 26 \\
\hline Sum $1+2$ & 62 & 34 & 28 & 47 & 15 & 34 & 28 \\
\hline Total number & 352 & 233 & 119 & 265 & 87 & 171 & 181 \\
\hline Index & 0.176 & 0.146 & 0.235 & 0.177 & 0.172 & 0.199 & 0.155 \\
\hline
\end{tabular}

Table 4. Knowledge 3

\begin{tabular}{|l|c|c|c|c|c|c|c|}
\hline $\begin{array}{c}\text { Businesses need a certain amount of } \\
\text { credit, but I think the entrepreneur should } \\
\text { have more equity than loans. }\end{array}$ & $\begin{array}{c}\text { Total } \\
\text { SMEs }\end{array}$ & Micro & OE & M & W & UD & OD \\
\hline 1. totally agree & 69 & 48 & 21 & 55 & 14 & 30 & 39 \\
\hline 2.agree & 185 & 125 & 60 & 128 & 57 & 81 & 104 \\
\hline Sum 1+2 & 254 & 173 & 81 & 183 & 71 & 111 & 143 \\
\hline Total number & 352 & 233 & 119 & 265 & 87 & 171 & 181 \\
\hline Index & 0.722 & 0.742 & 0.680 & 0.691 & 0.816 & 0.649 & 0.790 \\
\hline
\end{tabular}

Table 5. Knowledge 4

\begin{tabular}{|l|c|c|c|c|c|c|c|}
\hline $\begin{array}{c}\text { Debt should be used primarily to finance } \\
\text { the current capital of the company. }\end{array}$ & $\begin{array}{c}\text { Total } \\
\text { SMEs }\end{array}$ & Micro & OE & M & W & UD & OD \\
\hline 1. totally agree & 7 & 4 & 3 & 6 & 1 & 3 & 4 \\
\hline 2. agree & 105 & 68 & 37 & 82 & 23 & 52 & 53 \\
\hline Sum 1+2 & 112 & 72 & 40 & 88 & 24 & 55 & 57 \\
\hline Total number & 352 & 233 & 119 & 265 & 87 & 171 & 181 \\
\hline Index & 0.318 & 0.309 & 0.336 & 0.332 & 0.276 & 0.322 & 0.315 \\
\hline
\end{tabular}

Based on the results of the empirical research, we calculated the indicators $\mathrm{I}_{\mathrm{Ky}}, \mathrm{I}_{\mathrm{Kn}}$ and compared the value $\mathrm{I}_{\mathrm{Ky}}$ with the $\mathrm{I}_{\mathrm{Kn}}$ value:

$$
\begin{array}{lll}
\mathrm{I}_{\mathrm{Ky}}=0.676 & \mathrm{I}_{\mathrm{Kn}}=\left(\mathrm{I}_{\mathrm{K} 1}+\mathrm{I}_{\mathrm{K} 2}+\mathrm{I}_{\mathrm{K} 3}+\mathrm{I}_{\mathrm{K} 4}\right) / 4=0.381 & \mathrm{I}_{\mathrm{Ky}}>\mathrm{I}_{\mathrm{Kn}} \\
\mathrm{I}_{\mathrm{Ky}} / \mathrm{Micro}=0.674 & \mathrm{I}_{\mathrm{Kn}} / \mathrm{Micro}=0.354 & \mathrm{I}_{\mathrm{Ky}} / \mathrm{Micro}>\mathrm{I}_{\mathrm{Kn}} / \mathrm{Micro} \\
\mathrm{I}_{\mathrm{Ky}} / \mathrm{OE}=0.681 & \mathrm{I}_{\mathrm{Kn}} / \mathrm{OE}=0.433 & \mathrm{I}_{\mathrm{Ky}} / \mathrm{OE}>\mathrm{I}_{\mathrm{Kn}} / \mathrm{OE} \\
\mathrm{I}_{\mathrm{Ky}} / \mathrm{M}=0.660 & \mathrm{I}_{\mathrm{Kn}} / \mathrm{M}=0.379 & \mathrm{I}_{\mathrm{Ky}} / \mathrm{M}>\mathrm{I}_{\mathrm{Kn}} / \mathrm{M} \\
\mathrm{I}_{\mathrm{Ky}} / \mathrm{W}=0.724 & \mathrm{I}_{\mathrm{Kn}} / \mathrm{W}=0.385 & \mathrm{I}_{\mathrm{Ky}} / \mathrm{W}>\mathrm{I}_{\mathrm{Kn}} / \mathrm{W} \\
\mathrm{I}_{\mathrm{Ky}} / \mathrm{UD}=0.713 & \mathrm{I}_{\mathrm{Kn}} / \mathrm{UD}=0.394 & \mathrm{I}_{\mathrm{Ky}} / \mathrm{UD}>\mathrm{I}_{\mathrm{Kn}} / \mathrm{UD} \\
\mathrm{I}_{\mathrm{Ky}} / \mathrm{OD}=0.641 & \mathrm{I}_{\mathrm{Kn}} / \mathrm{OD}=0.369 & \mathrm{I}_{\mathrm{Ky}} / \mathrm{OD}>\mathrm{I}_{\mathrm{Kn}} / \mathrm{OD}
\end{array}
$$


The research results showed that the declared value of the ability to manage the credit risk $\left(\mathrm{I}_{\mathrm{Ky}}\right)$ effectively was higher than the average theoretical value of 0.500 in all defined groups of entrepreneurs. The highest value of this indicator was found in the group of female entrepreneurs (0.724) and the lowest value in the groups of entrepreneurs with a lower level of education (0.641). These results confirmed a relatively high self-confidence of entrepreneurs in managing the credit risk.

The average value of $\mathrm{I}_{\mathrm{Kn}}$ for the entire SME segment was lower than the average theoretical value of $\mathrm{I}_{\mathrm{Kn}}(0.500)$. The values of partial $\mathrm{I}_{\mathrm{Kn}}$ calculated for individual groups of entrepreneurs were lower than the average theoretical value of $\mathrm{I}_{\mathrm{Kn}}(0.500)$. The highest value of the indicator was found in the group of larger companies $(0.433)$ and the lowest in the group of micro-enterprises (0.354). These results confirmed the low level of the entrepreneurial knowledge in the field of the corporate capital management.

The H1 hypothesis was confirmed.

The H2 hypothesis was not confirmed.

The research results that quantify the relationship between the dependent variable and the independent variables are shown in the following tables.

Table 6. Skewness, kurtosis, z- value and Bartlett's test of independent variables

\begin{tabular}{|c|c|c|c|c|c|}
\hline \multirow{2}{*}{$\begin{array}{c}\text { Independent } \\
\text { Variable }\end{array}$} & \multicolumn{2}{|c|}{ Descriptive statistics } & \multicolumn{2}{|c|}{$\begin{array}{c}\text { Tests to verify the assumption of the normal distribution } \\
\text { and the homoscedasticity distribution }\end{array}$} \\
\cline { 2 - 5 } & $\begin{array}{c}\text { Skewness } \\
(\mathrm{S})\end{array}$ & $\begin{array}{c}\text { Kurtosis } \\
(\mathrm{K})\end{array}$ & $\begin{array}{c}\text { Z-value } \\
(\mathrm{S})\end{array}$ & $\begin{array}{c}\text { Z-value } \\
(\mathrm{K})\end{array}$ & Bartlett's test \\
\hline K1 & 1.354 & 1.254 & 1.681 & 0.624 & 0.348 \\
\hline K2 & 1.002 & 0.358 & 1.119 & -0.458 & 0.264 \\
\hline K3 & 2.654 & 0.735 & 4.824 & -0.347 & 0.017 \\
\hline K4 & 2.168 & 1.231 & 2.344 & 3.149 & 0.009 \\
\hline
\end{tabular}

The results in Table 6 show that the independent variables $(\mathrm{K} 1, \mathrm{~K} 2)$ meet the assumption of the normal distribution of the respondents' responses $(\mathrm{K} 1$ : z-value $(\mathrm{S})=1.681$, z- value $(\mathrm{K})=0.624, \mathrm{~K} 2$ : 1.119, z-value $(\mathrm{K})=-0.458)$. At the same time, $\mathrm{K} 1$ and $\mathrm{K} 2$ indicators meet the assumption of homoscedasticity, because Bartlett's p-value is higher than the significance level. The graphical analysis of the data, using the point graph, shows only slight variations in the pairing assessment of the respondents for the indicators K1 and K2. And vice versa, K3 and K4 do not meet the assumption of normality, linearity or homoscedasticity. The results of the correlation matrix indicate strong or very strong dependencies between respondents' responses to the Ky indicator (effective credit risk management) and its determinants (knowledge of the entrepreneur in the field of the corporate capital). The results of paired t-tests of the dependent variable Ky and the independent variables $(\mathrm{K} 3$ : $\mathrm{t}$-test $=1.153 ; \mathrm{K} 4$ : $\mathrm{t}$-test $=0.846)$ confirmed the statistical insignificance of the regression model parameters. But the independent variables $\mathrm{K} 1$ and $\mathrm{K} 2$ are suitable for describing the dependence using a suitable regression model. 
Table 7. Characteristics of regression model of the effective credit risk management

\begin{tabular}{|c|c|c|c|c|}
\hline \multicolumn{5}{|c|}{ Least squares multiple regression } \\
\hline \multicolumn{3}{|c|}{ Coefficient of determination $\left(\mathrm{R}^{2}\right)$} & \multicolumn{2}{|c|}{0.4825} \\
\hline \multicolumn{3}{|c|}{ Adjusted coefficient of determination (Adj. $\mathrm{R}^{2}$ ) } & \multicolumn{2}{|c|}{0.4801} \\
\hline \multicolumn{3}{|c|}{ Multiple correlation coefficient $(\mathrm{R})$} & \multicolumn{2}{|c|}{0.6946} \\
\hline \multicolumn{3}{|c|}{ Residual standard deviation } & \multicolumn{2}{|c|}{0.2158} \\
\hline \multicolumn{5}{|c|}{ Regression equation } \\
\hline Independent variables & Coefficient & Std. Error & t- Stat & $\mathrm{p}$-value \\
\hline \multicolumn{5}{|l|}{ Constant } \\
\hline $\mathrm{K} 1$ & 0.5581 & 0.1421 & 3.9275 & 0.008 \\
\hline $\mathrm{K} 2$ & 0.3159 & 0.0958 & 3.2975 & 0.014 \\
\hline \multicolumn{5}{|c|}{ Analysis of variance (ANOVA) } \\
\hline \multicolumn{3}{|c|}{ F-ratio } & \multicolumn{2}{|c|}{51.607} \\
\hline \multicolumn{2}{|c|}{ Significant level (p-value) } & & \multicolumn{2}{|c|}{$<0.001$} \\
\hline
\end{tabular}

To describe the dependence between the dependent variable (Ky) and the independent variables (K1, K2) we used a regression model with multiple linear function. The selected regression model best explains the overall variability of the effective credit risk management $(\mathrm{R} 2=0.4825)$. The selected linear regression model is statistically significant because the significant level of $\mathrm{F}$ - test is less than the significance level of the regression model.

Based on the results of the regression modelling characteristics (see Table 7), we formulated the relationship between the effective credit risk management and its determinants. The mathematical function of the regression model has the form:

$$
\mathrm{Ky}=0.5581 * \mathrm{~K} 1+0.3159 * \mathrm{~K} 2 \text {, }
$$

where Ky - effective credit risk management, K1 - I use debt, i.e. bank loan because it is cheaper than equity; $\mathrm{K} 2$ - debt, i.e. bank loan is less risky than equity.

\section{The H3 hypothesis was confirmed.}

The multiple linear regression model explains more than $30 \%$ of the total variability between the dependent variable Ky and the independent variables $(\mathrm{K} 1, \mathrm{~K} 2, \mathrm{~K} 3, \mathrm{~K} 4)$. The shape of the regression model explains up to $48.25 \%$ of the overall variation of the entrepreneurs' responses to Ky. A significant influence on the formation of effective attitudes of the entrepreneur to the management of the credit risk have K1 and K2. In our research, we found out that K3 and K4 do not have a statistically significant impact on the formation of effective attitudes of entrepreneurs to the credit risk management.

In Table 8 we compare the attitudes of entrepreneurs, according to business, gender, and education.

Table 8. Calculation of Z-score for individual indicators

\begin{tabular}{|l|c|c|c|c|c|}
\hline \multicolumn{1}{|c|}{ Z-score: $p$-value } & Ky & K1 & K2 & K3 & K4 \\
\hline Micro/OE & 0.8966 & $\mathbf{0}$ & $\mathbf{0 . 0 3 7 5}$ & 0.2225 & 0.6031 \\
\hline M/W & 0.2713 & 0.4715 & 0.9124 & $\mathbf{0 . 0 2 3 2}$ & 0.3271 \\
\hline UD/OD & 0.1471 & $\mathbf{0 . 0 0 0 1}$ & 0.2757 & $\mathbf{0 . 0 0 3 2}$ & 0.8887 \\
\hline
\end{tabular}

Values of the test criterion ( $p$-value $=0.8966 / 0.2713 / 0.1471$ ) confirmed that there are no statistically significant differences in the attitudes of entrepreneurs within the defined groups to assess their own ability to manage the credit risk. 
When evaluating K1 indicator, we found that there are statistically significant differences in respondents' responses. Larger businesses and entrepreneurs with higher education showed better level of knowledge (p-value $=0 / 0.0001)$.

Considering K2 indicator, we found that there are statistically significant differences in respondents' answers. Larger businesses presented higher level of knowledge in the field of the capital risk ( $p$-value $=0.0375$ ).

Taking K3 indicator into account, we found that there are statistically significant differences in respondents' answers. Women entrepreneurs and entrepreneurs with lower level of education declared a higher tendency to prudent management of the corporate capital ( $p$-value $=0.0232 / 0.0032$ ).

When we assess the K4 indicator, we found that there are no statistically significant differences in respondents' answers considering the defined groups of respondents.

\section{H4 was partially confirmed.}

The results of our research showed a relatively low correlation between the declared ability to manage the credit risk effectively and the average level of knowledge of the corporate capital because up to $68 \%$ of entrepreneurs declared that they are able to manage the credit risk effectively, but only $38 \%$ of them demonstrated their knowledge of indicators $\mathrm{K} 1$ to $\mathrm{K} 4$, which significantly determine the correct attitude towards the credit risk management.

Entrepreneurs demonstrated a relatively low level of knowledge of the corporate capital because only $31 \%$ of them agreed with the claim that debt is cheaper than equity. The lowest level of knowledge was demonstrated by entrepreneurs in assessing the risk of debt, where we found that only $18 \%$ of them understood correctly the mutual risk ratio of both types of capital.

In our research, entrepreneurs demonstrated a relatively responsible approach to the corporate equity management, as up to $72 \%$ of them agreed with the claim that the entrepreneur should have a higher volume of equity than loans.

Only $32 \%$ of entrepreneurs agreed that debt should be primarily used to finance the current capital of the company.

The results of our research, to some extent, confirmed the conclusions of Moon and Sohn (2010) about the impact of the firm-specific characteristics on the effective credit risk management and about the corporate size impact on the credit risk management (Gupta et al., 2015, Pervan, Kuvek, 2013) and about the impact of the personality characteristics and gender of the credit risk management (Kozubikova and Bartos, 2015; Kozubíková et al., 2015; Kozubíková et al., 2017). Our research also confirmed the conclusions of Irwin and Scott (2010) about the importance of education in the entrepreneurship.

In the results of our research, we can see a number of dissemination lines as well as clear microeconomic and macroeconomic significance.

The SME sector in the Czech business environment is comparable, in quantitative terms, to the situation in other EU countries, but considering a qualitative side, the situation is much more complicated, related to the more problematic adaptability of SMEs to changes in external conditions. The development of SMEs is complicated by complex, often changing legislations, taken without any analyses of impact on the business environment, high administrative burdens of business, bureaucratic interventions, public sector inefficiency, increase of input prices, lack of resources for start-up entrepreneurs, malfunctioning capital market, fragmented financial and other support of SMEs, inadequate interconnection of the education and training systems with the needs of the labor market and with the requirements of SMEs. 
These factors are important in the process of maintaining the sustainability of the SME sector, as their importance in the post-crisis period increase. High demands on knowledge are also made on entrepreneurs and business executives who find themselves in more complex decision-making situations associated with the financial management. Current education processes embedded in separate systems are inadequate or do not reflect the current needs of practice in the field of the financial management knowledge as well as changes in the external environment of companies, etc. This creates a potential for risks in several dimensions of the financial management of SMEs. We also see the importance of this issue taking the current global insolvency development of companies into account, which implicitly determines the sustainability of the SME sector. From an aggregate point of view, looking at the insolvency development of companies, the global insolvency rate was declining to 2017, but in the last few months there was a very low decline. Experts estimate a gradual increase in insolvency for 2017. The world insolvency index, Euler Hermes, declined by only 2\% between November and December, with an expected increase of $1 \%$ in the global insolvency. The increasing rate of insolvency is particularly peculiar to the US, Russia and China. For companies, it means a strong deflationary pressure and a slump in the global demand. Looking at the insolvency assumption for 2017 (Business Insolvency Worldwide - Economic Outlook 1230-1231, November-December 2016), the planned decrease in the Czech Republic is 7\% which is less than in Portugal (8\%) and more than in Slovakia (5\%). A significant decline in insolvency is expected this year in Denmark (19\% annual rate) and in Hungary (25\% annual rate). From the home environment, interesting research findings were provided by Ředinová and Paseková (2013) who searched the attitudes of SME owners to insolvency in the Czech and Slovak Republics (more than 130 respondents in each country).

The results of their study show that up to half of respondents have some experience with insolvency of their own business or their business partner. The attitudes of managers and owners of SMEs to insolvency and experience with it were almost the same in both countries. In both countries, less than a fifth of respondents thought about changing the seat of the company due to tax profitability. More than $60 \%$ of respondents in the Czech and Slovak Republics consider insolvency processes to be the business-termination related events, less than $10 \%$ of respondents would be passively waiting for the reaction of creditor in the event of insolvency. In both countries, there was a tendency to address the problem of their insolvency actively, highlighting the need for a wide range of knowledge in the field of the financial management of companies and the related financial security of companies. Here we can see a significant disproportion in the transfer of these findings to educational structures and policies. Despite the availability of the wide range of research studies dealing with financial literacy and its importance for the economy of the country, we can see the research flows only in the direction of initiating and realizing of the research and disseminating of their outcomes to the target subjects. An active feedback, a reflection on identified needs in the education, a transfer of knowledge into national strategic plans, regional concepts and programs are implemented in a minimal range. This leads to the deepening of disproportions and discrepancies among the research sphere, entrepreneurial practice and the sphere of policies.

\section{Conclusion}

The aim of this article was to search the dependence between the entrepreneur's ability to manage the corporate credit risk effectively and their knowledge of the corporate capital. The process and result trajectory of the research was focused on highlighting the financial security as well as the sustainability of the SME sector which are causally related. The importance of the research on the financial security and sustainability of the SME sector is increasing in the current post-crisis period.

The results of our research brought an interesting finding. Despite the fact, that entrepreneurs declared a relatively high ability of the effective credit risk management in their companies, they demonstrated a relatively low level of knowledge in managing the corporate capital.

Entrepreneurs in the SME segment have limited knowledge in the process of the credit risk management, which creates a potential growth of the corporate financial risk.

A significant impact on the formation of effective attitudes of the entrepreneur to manage the credit risk have 
indicators $\mathrm{K} 1$ and $\mathrm{K} 2$. In our research, we found that indicators $\mathrm{K} 3$ and $\mathrm{K} 4$ do not have statistically significant effect on the formation of effective attitudes of entrepreneurs to the credit risk management.

Our results confirmed that larger companies (compared to microenterprises), men (compared to women) and entrepreneurs with higher education (compared to lower-level education) have better level of knowledge of the corporate capital management.

Our research, similarly to comparable researches, has some limitations (e.g. sample size, definition of indicators), but it is beneficial as it creates a platform for further and deeper future research of processes of the financial security and sustainability of the companies in the SME sector.

The findings of our research have open a space for a deeper insight into the dimensions of the financial security of companies in the SME sector that absent in the scientific studies, particularly for its methodological difficulty and data limitation. Financial security of companies, in the context of the findings, is planned to be further analyzed considering several financial processes in companies and to model the financial scenarios on a quantitative and qualitative basis for a deeper study of the financial security of the companies and their sustainability.

Our ambition is also an active dissemination of these outputs to monitoring and evaluating reports, development concepts, national policies, and thus to encourage relevant institutions to find the possibilities of more effective support of SME entrepreneurs at different stages of their life cycle as well as to various unpredictable and predictable changes in national and international environments. This will greatly enhance the relevance of research studies for science and practice and open a space for further research of this issue.

\section{Acknowledgement}

This work was supported by the Slovak Research and Development Agency under Grant number APVV-140841: Comprehensive Prediction Model of the Financial Health of Slovak Companies.

\section{References}

Akhmadeev, B.; Manakhov, S. 2015. Effective and sustainable cooperation between start-ups, venture investors, and corporations, Journal of Security and Sustainability Issues 5(2): 269-284. http://dx.doi.org/10.9770/jssi.2015.5.2(12)

Altman, EI., Sabato, G., Wilson, N. 2010. The value of non-financial information in small and medium-sized enterprise risk management, Journal of Credit Risk, 6(2): 95-127.

Astrauskaitè, I.; Paškevičius, A. 2016. Assessing the optimal taxation of the capital income: a case of corporate bond market, Journal of Security and Sustainability Issues 5(4): 519-532. http://dx.doi.org/10.9770/jssi.2016.5.4(7)

Ayub, A., Razzaq, A., Aslam, M.S., Iftekhar, H. 2013. Gender effects on entrepreneurial orientation and value innovation: evidence from Pakistan, European Journal of Business and Social Sciences, 2(1): 82-90.

Bain \& Company, Inc. and The Institute of International Finance. 2013. Restoring Financing and Growth to Europe's SMEs. Available on the Internet: http://www.bain.com/Images/REPORT_Restoring_financing_and_growth_to_Europe's_SMEs.pdf

Behr, P. Guttler, A. 2007. Credit risk assessment and relationship lending: An empirical analysis of German small and medium-sized enterprises, Journal of Small Business Management, 45(2): 194-213.

Chen, TK. 2016. Does geography matter in a geographically small and culturally homogeneous country? Firm location and corporate credit risk, International Review of Economics \& Finance, 44: 323-348. http://dx.doi.org/10.1016/j.iref.2016.02.007

Czarniewski, S. 2016. Small and Medium-Sized Enterprises in the Context of Innovation and Entrepreneurship in the Economy, Polish Journal of Management Studies, 13(1): 30-39.

Dangl, T., Zechner, J. 2004. Credit risk and dynamic capital structure choice, Journal of Financial Intermediation, 13(2): $183-204$.

Diaz-Garcia, M. C., Jimenez-Moreno, J. 2010. Entrepreneurial intention: the role of gender, International Entrepreneurship Management Journal, 6: 261-283. 
Felicio, J. A., Galindo Villardón, M. P. 2015. Family characteristics and governance of small and mediun-sized family firms, Journal of Business Economics and Management, 16(6):1069-1084. http://dx.doi.org/10.3846/16111699.2012.747446

Gamage, P. 2013. Determinants of Access to Bank Finance for Small and Medium- sized Enterprises: the Case of Sri Lanka, Corporate Ownership and Control, 10(3).

Garwe, D. K., Fatoki, O. 2012. The Impact of Gender on SME Characteristics and Access to Debt Finance in South Africa, Development Southern Africa, 29(3). http://dx.doi.org/10.1080/0376835X.2012.706040

Giriūnienè, G.; Giriūnas, L. 2015. Sustainable development and tax system: it's impact on entrepreneurship, Journal of Security and Sustainability Issues 4(3): 233-240. http://dx.doi.org/10.9770/jssi.2015.4.3(4)

Grossl, I., Stahlecker, P., Wohlers, E. 2001. An empirical investigation of German firms' financial structure and ensuing risks, Jahrbucher fur Nationalokonomie und Statistik, 221(5-6): 491-529.

Gupta, J., Gregoriou, A., Healy, J. 2015. Forecasting bankruptcy for SMEs using hazard function: To what extent does size matter? Review of Quantitative Finance and Accounting, 45(4): 845-869. http://dx.doi.org/10.1007/s11156-014-0458-0

Hackbarth, D., Miao, J., Morellec, E. 2006. Capital structure, credit risk, and macroeconomic conditions, Journal of Financial Economics, 82(3): 519-550. http://dx.doi.org/10.1016/j.jfineco.2005.10.003

Hair, J. F., Black, W. C., Babin, B. J., Anderson, R. E. 2010. Multivariate data analysis. New Jersey: Upper Saddle River: Prentice Hall.

Havierniková, K., Okręglicka M., Lemańska-Majdzik A. 2016. Cluster Cooperation and Risk Level in Small and Medium-Sized Enterprises, Polish Journal of Management Studies, 14(2): 82-92.

International Finance Corporation 2013. IFC Jobs Study: Assessing Private Sector Contributions to Job Creation and Poverty Reduction.

Irwin, D., Scott, J. M. 2010. Barriers Faced by SMEs in Raising Bank Finance, International Journal of Entrepreneurial Behavior and Research, 16(9). http://dx.doi.org/10.1108/13552551011042816

Kim, S., Seo, J.Y., Sohn, P. 2011. SMEs' capital structure behavior on cash holdings to Korean financial crisis: The evidence from emerging market, African Journal of Business Management, 5(34): 13095-13115. http://dx.doi.org/10.5897/AJBM11.2270

Kislingerová, E. et al. 2010. Manažerské finance. Praha: C. H. Beck.

Ključnikov, A., Popesko, B. 2017. Export and its Financing in the SME Segment. Case Study from Slovakia, Journal of Competitiveness, 9(1): 20 -35. http://dx.doi.org/10.7441/joc.2017.01.02

Kozarevic, E., Jukan, MK., Softic, A. 2015. An Overview of Small and Medium- Sized Banking Development in Bosnia and Herzegovina, Journal of Economic and Social Studies, 5(1): 107-125. http://dx.doi.org/10.14706/JECOSS11519

Kozubikova, L., Bartos, P. 2015. Personality types of entrepreneurs and selected attributes of credit risk in the sme segment. A case study from Czech Republic and Slovakia, Proceeding of 7th International Scientific Conference on Finance and Performance of Firms in Science, Education and Practice, Zlin, Czech Republic, 728-737.

Kozubíková, L., Belas, J., Bilan, Y., Bartos, P. 2015. Personal characteristics of entrepreneurs in the context of perception and management of business risk in the SME segment, Economics and Sociology, 8(1): 41-54. http://dx.doi.org/10.14254/2071- 789X.2015/8-1/4

Kozubíková, L., Homolka, L., Kristalas, D. 2017. The Effect of Business Environment and Entrepreneurs' Gender on Perception of Financial Risk in the SMEs Sector, Journal of Competitiveness, 9(1): 36 - 50. http://dx.doi.org/10.7441/joc.2017.01.03

Krejčí, M., Strielkowski, W., Čabelková, I. 2015. Factors That Influence The Success of Small and Medium Enterprises in ICT: A Case Study from The Czech Republic, Business: Theory and Practise, 16(3): 304-315.

Kritzman, M., Li, YZ. 2010. Skulls, Financial Turbulence, and Risk Management, Financial Analysts Journal, 66(5): 30-41. http://dx.doi.org/10.2469/faj.v66.n5.3

Kulišauskas, D.; Galinienè, B. 2015. Stock evaluation methods and their applicability in Lithuania ensuring sustainable capital market development, Journal of Security and Sustainability Issues 5(1): 73-86. 10.9770/jssi.2015.5.1(6)

Kundin, A., Erecgovac, R. 2011. Credit Rationing in Financial Distress: Croatia's SMEs Finance Approach, International Journal of Law and Management, 53(1). 
Lafuente, E.M., Vaillant, Y. 2013. Age Driven Influence of Role-Models on Entrepreneurship in a Transition Economy, Journal of Small Business and Enterprise Development, 20(1): 181-203.

Leopoulos, V.N., Kirytopoulos, K. A., Malandrakis, C. 2006. Risk management for SMEs: Tools to use and how, Production Planning \& Control, 17(3): 322-332. http://dx.doi.org/10.1080/09537280500285136

Lim, S., Envick, E.R. 2011. Gender and Entrepreneurial Orientation: A Multi Country Study, International Entrepreneurship and Management Journal, 9(3): 465-482.

Marshall, C., Prusak, L., Shpilberg, D. 1996. Financial risk and the need for superior knowledge management, California Management Review, 38(3): 77-\&.

Merigó, J. M. 2015. Decision-making under risk and uncertainty and its application in strategic management, Journal of Business Economics and Mnagement, 16(1): 93-116. http://dx.doi.org/10.3846/16111699.2012.661758

Moon, TH., Sohn, SY. 2010. Technology credit scoring model considering both SME characteristics and economic conditions: The Korean case, Journal of the Operational Research Society, 61(4): 666-675. http://dx.doi.org/10.1057/jors.2009.7

Munteanu, C.; Tamošiūnienè, R. 2015. Modern approaches in quantifying economic security. Case study of Estonia, Latvia, Lithuania and Republic of Moldova, Journal of Security and Sustainability Issues 4(4): 596-610. http://dx.doi.org/10.9770/jssi.2015.4.4(2)S

Naude, W., Gries, T., Wood, E., Meintjiess, A. 2008. Regional determinants of Entrepreneurial Startups in a Developing Country, Entrepreneurship and Regional Development, 20(2): 111-124.

Noriss, M., Lecavalier, L. 2009. Evaluating the Use of Exploratory Factor Analysis in Developmental Disability Psychological Research, Journal of Autism and Developmental Disorders, 40(1): 8-20. DOI: http://dx.doi.org/10.1007/s10803-009-0816-2

Pavelka L., Krchnak P. 2015. Competitive advantages of internationally operating companies, Ekonomicko-manazerske spektrum, 9(2): $2-6$.

Pavelková, D., Knápková, A. 2005. Výkonnost podniku z pohledu finančniho manažéra (Performance of the enterprise from the perspective of the financial manager). Praha: Linde.

Pervan, I., Kuvek, T. 2013. The relevant Importance of Financial Ratios and Non-Financial variables in Predicting of Insolvency, Croatian Operational research review, 4(1): 187-197.

Purnanandam, A. 2008. Financial distress and corporate risk management: Theory and evidence, Journal of Financial Economics, 87(3): 706-739.

Ramlee, S., Berma, B. 2013. Financing Gap in Malaysian Small and Medium Enterprises: a Supply-side Perspective, South African Journal of Economics and Management Sciences, 16.

Rauch, A., Rijsdijk, S.A. 2013. The Effects of General and Specific Human Capital on long-Term Growth and Failure of Newly Founded Businesses, Entrepreneurship Theory and Practice, 37(4): 923-941.

Redinová, H., Paseková, M. 2013. Postoje vlastníků malých a středních podniků k problematice insolvence v České republice a Slovenské republice, Trendy ekonomiky a management, VII(13): 53-68.

Smrčka, L., Plaček, J., Schönfeld, J., Louda, L. 2016. Insolvenční ř́zení. Praha: Professional Publishing.

Stan-Maduka, E. 2013. SME Financial Management: A Risk Management Perspective, Enterprise Development in SMEs and Entrepreneurial Firms: Dynamic Processes, 330-342. DOI: 10.4018/978-1-4666-2952-3.ch018

Stasytytė, V., Aleksienė, L. 2015. Operational risk assessment and management in small and medium-sized enterprises, Business:Theory and Practice 16(2): 140-148. http://dx.doi.org/0.3846/btp.2015.568

Tamulevičienè, D. 2016. Methodology of complex analysis of companies' profitability, Entrepreneurship and Sustainability Issues4(1): 53-63. https://doi.org/10.9770/jesi.2016.4.1(5)

Travkina, I.; Tvaronavičienė, M. 2015. Peculiarities of export structure in Lithuania: synthesis and analysis, Entrepreneurship and Sustainability Issues 2(4): 233-247. https://doi.org/10.9770/jesi.2015.2.4(7)

Tvaronavičienė, M. 2016. Start-ups across the EU: if particular tendencies could be trace, Entrepreneurship and Sustainability Issues 3(3): 290-298. https://doi.org/10.9770/jesi.2016.3.3(6) 
Van der Sluis, J., Van Praag, M. 2008. Education and Entrepreneurship Selection and Performance: A Review of the Empirical Literature, Journal of Economic Surveys, 22(5): 795-841.

Velez, C.M. 2009. The Probability of Transition to Entrepreneurship Revisited: Wealth, Education and Age, Annals of Finance, 5(3): 421-441.

Virglerova, Z., Dobes, K., Vojtovic, S. 2016. The Perception of the States Influence on its Business Environment in the SMEs from Czech Republic, Administratie si Management Public, 14(26): 78-96. http://www.socscistatistics.com/tests/ztest/Default2.aspx

Prof. Dr. Jaroslav BELAS is a renowned expert in banking, financial markets, and risk management of SMEs. Previously worked in the banking sector of Slovakia. In academic field he has worked at the University of Economics in Bratislava, Banking Institutions University of Prague, and the Pan European University in Bratislava. He is currently at Tomas Bata University in Zlin, Faculty of Management and Economics. He is an author of 8 monographs; the results of the research activities have been outputted through 50 various scientific works that have been published in prestigious journals in peer-reviewed scientific journals in the Web of Science and Scopus database, and other scientific journals.

Maria MISANKOVA, PhD. works as a lecturer at the Department of Economics at the Faculty of Operation and Economics of Transport and Communications od the University of Zilina. She focuses in her research especially on bankruptcy prediction and financial health of companies, credit risk management, financial markets, financial and strategic management. She has participated in four research projects dedicated to the issues of her interest.

ORCID ID: orcid.org/0000-0003-2081-6835

Dr. Jaroslav SCHONFELD was graduated from the University of Economics in Prague in 2007. He works in the Czech Savings Bank, Since 2008 gives lestures on the University of Economics, Prague. The focus of his interest is the transformation, restructuring and recovery of firms, managerial finance, business valuation and bankruptcy processes. He is constantly involved in research programm at the faculty. He was involved in two scientific project from the Technology Agency of The Czech Republic. He is the author of two monographs and co-author of numerous other books and articles in scientific journals listed in Web of Science database or Scopus.

Assoc. Prof. Beata GAVUROVA, PhD. is an expert in finance, financial analysis and financial risk management. She focuses in her research work on issues of measurement and performance management in various sectors, process management and process optimization, strategic and performance benchmarking. Her dominant research area is the development and testing in management and performance measurement, evaluation of methodologies and preparing of application platform for innovative management and performance measurement with the support of ICT. 